\title{
Infant mortality in Pelotas, Brazil: a comparison of risk factors in two birth cohorts
}

\author{
Ana Maria Baptista Menezes, ${ }^{1}$ Pedro Curi Hallal, ${ }^{1}$ Iná Silva dos Santos, ${ }^{1}$ \\ Cesar Gomes Victora, ${ }^{1}$ and Fernando Celso Barros ${ }^{2}$
}

Suggested citation Menezes AMB, Hallal PC, Santos IS, Victora CG, Barros FC. Infant mortality in Pelotas, Brazil: a comparison of risk factors in two birth cohorts. Rev Panam Salud Publica. 2005;18(6):439-46.

ABSTRACT Objectives. To compare two population-based birth cohorts to assess trends in infant mortality rates and the distribution of relevant risk factors, and how these changed after an 11year period.

Methods. Data from two population-based prospective birth cohorts (1982 and 1993) were analyzed. Both studies included all children born in a hospital (>99\% of all births) in the city of Pelotas, Southern Brazil. Infant mortality was monitored through surveillance of all maternity hospitals, mortality registries and cemeteries.

Results. There were 5914 live-born children in 1982 and 5249 in 1993. The infant mortality rate decreased by 41\%, from 36.0 per 1000 live births in 1982 to 21.1 per 1000 in 1993 . Socioeconomic and maternal factors tended to become more favorable during the study period, but there were unfavorable changes in birthweight and gestational age. Poverty, high parity, low birthweight, preterm delivery, and intrauterine growth restriction were the main risk factors for infant mortality in both cohorts. The 41\% reduction in infant mortality between 1982 and 1993 would have been even greater had the prevalence of risk factors remained constant during the period studied here.

Conclusions. There were impressive declines in infant mortality which were not due to changes in the risk factors we studied. Because no reduction was seen in the large social inequalities documented in the 1982 cohort, it is likely that the reduction in infant mortality resulted largely from improvements in health care.

Key words Infant mortality, inequalities, cohort studies, prospective studies, developing countries.

The infant mortality rate is widely used as an indicator of quality of life and level of socioeconomic development $(1,2)$. Although declines in infant

\footnotetext{
1 Post-Graduate Program in Epidemiology, Federal University of Pelotas, Brazil. Send correspondence and reprint requests to Ana Maria Baptista Menezes, Duque de Caxias 250, Third floor, 96030002 Pelotas, Brazil; telephone: (55) 533271 2442; fax: (55) 533271 2645; e-mail: anamene@terra.com.br

2 PAHO/WHO Latin American Center for Perinatology and Human Development, Montevideo, Uruguay.
}

mortality have been observed in most of the world $(2,3)$, socioeconomic inequities are still pervasive $(4,5)$. Relatively few studies have addressed changes in the frequency of risk factors for mortality outside high-income countries $(6,7)$, and even fewer studies have examined how the role of risk factors may change over time (8).

The availability of two birth cohort studies in Southern Brazil allowed us to assess time trends in infant mortal- ity and in the distribution of relevant risk factors in the population, and to explore whether changes in these factors could account for the observed trends in mortality.

\section{METHODS}

In 1982 and 1993, all maternity hospitals in the city of Pelotas (current urban population 320000 inhabitants) 
in Southern Brazil were visited daily, and all 5914 and 5249 live-born infants, respectively, were enrolled in a cohort study and followed up prospectively. Several variables were recorded during an interview with the mother and through examination of the newborn. These included socioeconomic (family income) and demographic variables (infant sex, maternal age and skin color), parity, pregestational weight (in $\mathrm{kg}$ ), maternal height (in $\mathrm{cm}$ ), maternal weight gain (in $\mathrm{kg}$ ), smoking during pregnancy (a dichotomous variable independent of the number of cigarettes smoked), birth interval (in months), gestational age (calculated from the reported date of the last menstrual period), intrauterine growth retardation (IUGR) according to the 10th percentile of the Williams curve (9), birthweight (in grams) and type of delivery (normal or cesarean).

Mortality surveillance included regular visits to all hospitals, cemeteries and death registries in the city. Information on the cause of death was obtained from pediatricians, case notes, autopsies and home visits. From interviews with the doctors and parents of these children, a full history of the events preceding death was obtained with the help of a questionnaire based on the Inter-American Investigation of Mortality in Childhood (1). Two independent pediatricians were responsible for determining the cause of death, and in case of discordance, a third referee was asked to help the team reach a final decision.

The infant mortality rate was expressed per 1000 live births, and unadjusted associations with risk factors were assessed with chi-squared tests for heterogeneity and linear trend. The multivariate analysis (logistic regression) was based on a conceptual framework of the hierarchy between determinants of infant mortality, according to the method proposed by Victora et al. (10). The first hierarchical level included infant sex, maternal skin color, and family income. The second level included characteristics of the mother around the time of conception, including age, height, pregestational weight, parity and birth interval; and the third level included characteristics of the pregnancy (maternal weight gain and smoking). The effect of maternal weight gain during pregnancy on the risk of infant mortality was also adjusted for gestational age because potential weight gain may have been reduced in cases of preterm delivery. The fourth level included gestational age and IUGR. The most proximate level comprised birthweight and type of delivery. Variables with a $P$ value $<0.20$ remained in the model as potential confounders. These analyses were carried out separately for each cohort.

A pooled database including a categorical variable to identify the cohort was also used. These analyses allowed us to investigate how much of the change in mortality could be attributed to changes in risk factors during the study period. Etiologic fractions for selected factors that influence the risk of infant mortality were calculated by estimating the proportion of deaths that would have been prevented if all children belonged to the lowest-risk category of the exposure variables.

Detailed information on the methodology for both cohorts is available elsewhere (11). Both studies were approved by the local Ethical Committee, and informed consent was obtained.

\section{RESULTS}

Nonresponse rates during recruitment were below $1 \%$ in both cohorts. Table 1 describes the two cohorts in terms of infant and maternal characteristics. There were increases in 1993 in the percentages of girls, and in the percentages of infants born to nonwhite mothers, high-income families, teenage mothers, high-parity women and to mothers with a weight gain during pregnancy under $8 \mathrm{~kg}$. On the other hand, smoking during pregnancy and birth intervals < 24 months were less frequent in 1993 than in 1982. The proportion of mothers shorter than $150 \mathrm{~cm}$ was much smaller in 1993, as was the percentage of mothers weighing less than $49 \mathrm{~kg}$. The proportion of newborns with IUGR and of preterm deliveries increased. Mean birthweight decreased by $30 \mathrm{~g}$ between 1982 and 1993.

The data for gestational age and IUGR should be interpreted with caution. Both depend on the reported date of the last menstrual period, a variable for which missing values represented $21.1 \%$ of all observations in 1982 and $11.8 \%$ in 1993 . Mothers with missing values tended to belong to families in lower socioeconomic levels.

Table 2 presents crude infant mortality rates for the subgroups of the proposed risk factors. Boys presented a significantly higher risk of infant mortality than girls in 1993, but not in 1982. Nonwhite skin color was associated with a greater risk of infant mortality in both cohorts, as was lower family income. Children born to adolescent mothers were more likely to die in the 1982 cohort, whereas in the 1993 cohort, children born to older mothers were at higher risk. Low maternal weight and height were risk factors for infant mortality in both cohorts. Maternal parity equal to or above four was related to an increased risk of infant mortality in both studies. The higher the maternal weight gain during pregnancy, the lower the risk of infant mortality. Maternal smoking was not associated with infant mortality in the crude analyses. A birth interval shorter than 24 months was associated with a higher risk of infant mortality in the 1982 cohort, but not in 1993. Birthweight showed a strong negative association with the risk of infant mortality, as did gestational age. Intrauterine growth restriction was associated with a higher risk of infant mortality in both cohorts, although the type of delivery showed no such association.

The last column in Table 2 shows the percent reduction in infant mortality within each category of risk factor. In 1993 there were reductions in all groups except for infants born to mothers aged 35 years and over (a 2\% increase) and to women who gained 15 $\mathrm{kg}$ or more during pregnancy (an $81 \%$ increase; results based on 10 deaths in 1982 and 21 deaths in 1993). The crude overall decline in the infant mortality rate between 1982 and 1993 was 41\%. 
TABLE 1. Demographic, socioeconomic and obstetric characteristics of the 1982 and 1993 cohorts of mothers and infants in Pelotas, Brazil

\begin{tabular}{|c|c|c|c|}
\hline Variable & $\begin{array}{c}1982 \\
(n=5914) \\
(\%)\end{array}$ & $\begin{array}{c}1993 \\
(n=5249) \\
(\%)\end{array}$ & $P$ value ${ }^{\mathrm{a}}$ \\
\hline Sex & & & 0.02 \\
\hline Male & 51.4 & 49.2 & \\
\hline Female & 48.6 & 50.8 & \\
\hline Maternal skin color & & & $<0.01$ \\
\hline White & 82.1 & 77.3 & \\
\hline Nonwhite & 17.9 & 22.7 & \\
\hline Family income (fold minimum wage) & & & $<0.01$ \\
\hline$\leq 1.0$ & 21.9 & 18.4 & \\
\hline $1.1-3.0$ & 47.4 & 43.1 & \\
\hline $3.1-6.0$ & 18.5 & 22.9 & \\
\hline $6.1-10.0$ & 6.5 & 8.3 & \\
\hline$>10.0$ & 5.7 & 7.3 & \\
\hline Maternal age (years) & & & $<0.01$ \\
\hline$<20$ & 15.4 & 17.4 & \\
\hline 20-34 & 74.7 & 71.6 & \\
\hline$\geq 35$ & 9.9 & 11.0 & \\
\hline Maternal height (cm) & & & $<0.01$ \\
\hline$<150$ & 11.0 & 4.6 & \\
\hline$\geq 150$ & 89.0 & 95.4 & \\
\hline Pregestational weight $(\mathrm{kg})$ & & & $<0.01$ \\
\hline$<49$ & 23.1 & 15.7 & \\
\hline$\geq 49$ & 76.9 & 84.3 & \\
\hline Parity & & & $<0.01$ \\
\hline $1 \mathrm{st}$ & 39.3 & 35.1 & \\
\hline 2nd & 28.1 & 27.8 & \\
\hline $3 r d$ & 16.3 & 18.0 & \\
\hline$\geq 4$ th & 16.3 & 19.1 & \\
\hline Maternal weight gain (kg) & & & 0.03 \\
\hline$<8$ & 20.8 & 22.7 & \\
\hline $8-14.9$ & 52.2 & 49.7 & \\
\hline$\geq 15$ & 27.0 & 27.6 & \\
\hline Maternal smoking during pregnancy & & & 0.02 \\
\hline No & 64.4 & 66.6 & \\
\hline Yes & 35.6 & 33.4 & \\
\hline Birth interval (months) & & & $<0.01$ \\
\hline$<24$ & 30.6 & 19.2 & \\
\hline$\geq 24$ & 69.4 & 80.8 & \\
\hline Birthweight $(\mathrm{g})^{\mathrm{b}}$ & & & 0.03 \\
\hline$<1500$ & 1.1 & 0.9 & \\
\hline 1500-1999 & 1.8 & 1.7 & \\
\hline 2000-2499 & 6.1 & 7.2 & \\
\hline 2500-2999 & 23.6 & 25.1 & \\
\hline$\geq 3000$ & 67.4 & 65.2 & \\
\hline Intrauterine growth restriction ${ }^{c}$ & & & 0.01 \\
\hline No & 85.2 & 83.3 & \\
\hline Yes & 14.8 & 16.7 & \\
\hline Gestational age (weeks) ${ }^{c}$ & & & $<0.01$ \\
\hline$<37$ & 6.3 & 10.8 & \\
\hline$\geq 37$ & 93.6 & 89.2 & \\
\hline Delivery type & & & $<0.01$ \\
\hline Normal & 72.4 & 69.5 & \\
\hline Cesarean section & 27.6 & 30.5 & \\
\hline
\end{tabular}

a Chi-squared test for heterogeneity.

b Mean birthweight decreased by $30 \mathrm{~g}$ between 1982 and 1993

${ }^{c}$ Values missing for $21.1 \%$ of the sample in 1982 and for $11.8 \%$ in 1993.

Table 3 presents odds ratios for infant mortality in the multivariate analyses. Most of the results of the crude analyses were confirmed. For the
1982 cohort, the following variables remained significant: family income, pregestational weight, parity, birth interval, maternal weight gain, gesta- tional age, IUGR and birthweight. In 1993, the significant variables were sex, maternal skin color, family income, maternal age, parity, gestational age, IUGR and birthweight.

Table 4 presents etiologic fractions of selected risk factors for infant mortality. In both cohorts, family income was the variable with the highest value: had all children been born to the highest family income group, $34.7 \%$ of the deaths in 1982 and $42.2 \%$ in 1993 would have been prevented. Birthweight ranked second in both cohorts, with etiologic fractions of $6.7 \%$ and $9.6 \%$, respectively.

Table 5 shows the analyses using year of birth as an exposure variable. The crude odds ratio for infant mortality in the 1993 cohort compared to the 1982 cohort was 0.58 , corresponding to a reduction in infant mortality ratio from 36 to 21 per 1000 . Had family and maternal variables remained unchanged between 1982 and 1993, the decline would have been smaller (OR of 0.70 , corresponding to an infant mortality ratio of 25 per 1000 ); because these characteristics improved during the study interval, they accounted for part of the reduction. However, characteristics of the newborns, particularly birthweight and gestational age, worsened during the period, and had these remained constant the predicted drop in mortality would have been even greater, from 36 to 15 per 1000 (last row in Table 5).

\section{DISCUSSION}

Comparison of the data from two population-based birth cohorts in Southern Brazil showed that the crude infant mortality rate declined by $41 \%$ between 1982 and 1993. Low birthweight, poverty, high parity, preterm delivery and IUGR were the main risk factors for infant mortality in both cohorts. There are two possible explanations for this decline: either there were important reductions in risk factor prevalence, or survival rates within each risk factor category improved for other reasons.

In terms of changes in familyrelated factors, there were significant 
TABLE 2. Infant mortality rate (IMR) in two population-based birth cohorts according to proposed risk factors in Pelotas, Brazil, 1982-1993

\begin{tabular}{|c|c|c|c|c|c|}
\hline \multirow[b]{2}{*}{ Variable } & \multicolumn{2}{|c|}{$\begin{array}{l}1982 \text { Cohort } \\
(n=5914)\end{array}$} & \multicolumn{2}{|c|}{$\begin{array}{c}1993 \text { Cohort } \\
(n=5249)\end{array}$} & \multirow[b]{2}{*}{$\begin{array}{l}\text { Percent } \\
\text { change }\end{array}$} \\
\hline & $\begin{array}{c}\text { IMR } \\
\text { (per } 1000)\end{array}$ & $P$ value ${ }^{\mathrm{a}}$ & $\begin{array}{c}\text { IMR } \\
\text { (per } 1000)\end{array}$ & $P$ value ${ }^{\mathrm{a}}$ & \\
\hline Sex & & 0.32 & & 0.04 & \\
\hline Male & 38.2 & & 25.2 & & -34 \\
\hline Female & 33.4 & & 16.9 & & -49 \\
\hline Maternal skin color & & $<0.01$ & & 0.003 & \\
\hline White & 31.7 & & 18.0 & & -43 \\
\hline Nonwhite & 55.7 & & 32.0 & & -43 \\
\hline Family income (fold minimum wage) & & $<0.01^{\mathrm{b}}$ & & $<0.01^{b}$ & \\
\hline$\leq 1.0$ & 72.2 & & 33.1 & & -54 \\
\hline $1.1-3.0$ & 32.3 & & 26.1 & & -19 \\
\hline $3.1-6.0$ & 15.6 & & 10.8 & & -31 \\
\hline $6.1-10.0$ & 18.3 & & 11.5 & & -37 \\
\hline$>10.0$ & 11.9 & & 5.2 & & -56 \\
\hline Maternal age (years) & & $0.06^{\mathrm{b}}$ & & $0.01^{b}$ & \\
\hline$<20$ & 49.3 & & 20.8 & & -58 \\
\hline $20-34$ & 33.1 & & 18.6 & & -44 \\
\hline$\geq 35$ & 37.5 & & 38.1 & & +2 \\
\hline Maternal height $(\mathrm{cm})$ & & $<0.01$ & & 0.05 & \\
\hline$<150$ & 76.9 & & 37.7 & & -51 \\
\hline$\geq 150$ & 30.2 & & 19.5 & & -35 \\
\hline Pregestational weight $(\mathrm{kg})$ & & $<0.01$ & & 0.05 & \\
\hline$<49$ & 45.4 & & 29.8 & & -34 \\
\hline$\geq 49$ & 27.7 & & 18.9 & & -32 \\
\hline Parity & & $<0.01$ & & $<0.01$ & \\
\hline 1st & 28.9 & & 17.9 & & -38 \\
\hline 2nd & 28.3 & & 17.1 & & -40 \\
\hline $3 r d$ & 39.4 & & 14.8 & & -62 \\
\hline$\geq 4$ th & 63.3 & & 39.0 & & -38 \\
\hline Maternal weight gain $(\mathrm{kg})$ & & $<0.01$ & & $<0.01$ & \\
\hline$<8$ & 53.4 & & 37.7 & & -29 \\
\hline $8-14.9$ & 25.7 & & 13.6 & & -47 \\
\hline$\geq 15$ & 8.4 & & 15.2 & & +81 \\
\hline Maternal smoking during pregnancy & & 0.14 & & 0.42 & \\
\hline No & 33.3 & & 20.0 & & -40 \\
\hline Yes & 40.9 & & 23.4 & & -43 \\
\hline Birth interval (months) & & $<0.01$ & & 0.23 & \\
\hline$<24$ & 61.4 & & 30.7 & & -50 \\
\hline$\geq 24$ & 30.2 & & 22.3 & & -26 \\
\hline Birthweight (g) & & $<0.01^{\mathrm{b}}$ & & $<0.01^{b}$ & \\
\hline$<1500$ & 703.1 & & 630.4 & & -10 \\
\hline $1500-1999$ & 229.4 & & 181.8 & & -21 \\
\hline $2000-2499$ & 110.8 & & 34.6 & & -69 \\
\hline 2500-2999 & 35.3 & & 13.7 & & -61 \\
\hline$\geq 3000$ & 12.8 & & 7.3 & & -43 \\
\hline Intrauterine growth restriction & & $<0.01$ & & $<0.01$ & \\
\hline No & 22.6 & & 11.9 & & -47 \\
\hline Yes & 57.8 & & 25.7 & & -56 \\
\hline Gestational age (weeks) & & $<0.01$ & & $<0.01$ & \\
\hline$<37$ & 18.5 & & 9.2 & & -49 \\
\hline$\geq 37$ & 170.1 & & 60.2 & & -65 \\
\hline Delivery type & & 0.37 & & 0.66 & \\
\hline Normal & 37.4 & & 20.6 & & -45 \\
\hline Cesarean section & 32.5 & & 22.5 & & -31 \\
\hline Overall & 36.0 & & 21.1 & & -41 \\
\hline
\end{tabular}

a Chi-squared test.

${ }^{\mathrm{b}}$ Chi-squared test for linear trend. 
TABLE 3. Risk factors for infant mortality in two population-based birth cohorts (multivariate analysis, logistic regression) in Pelotas, Brazil, 1982-1993

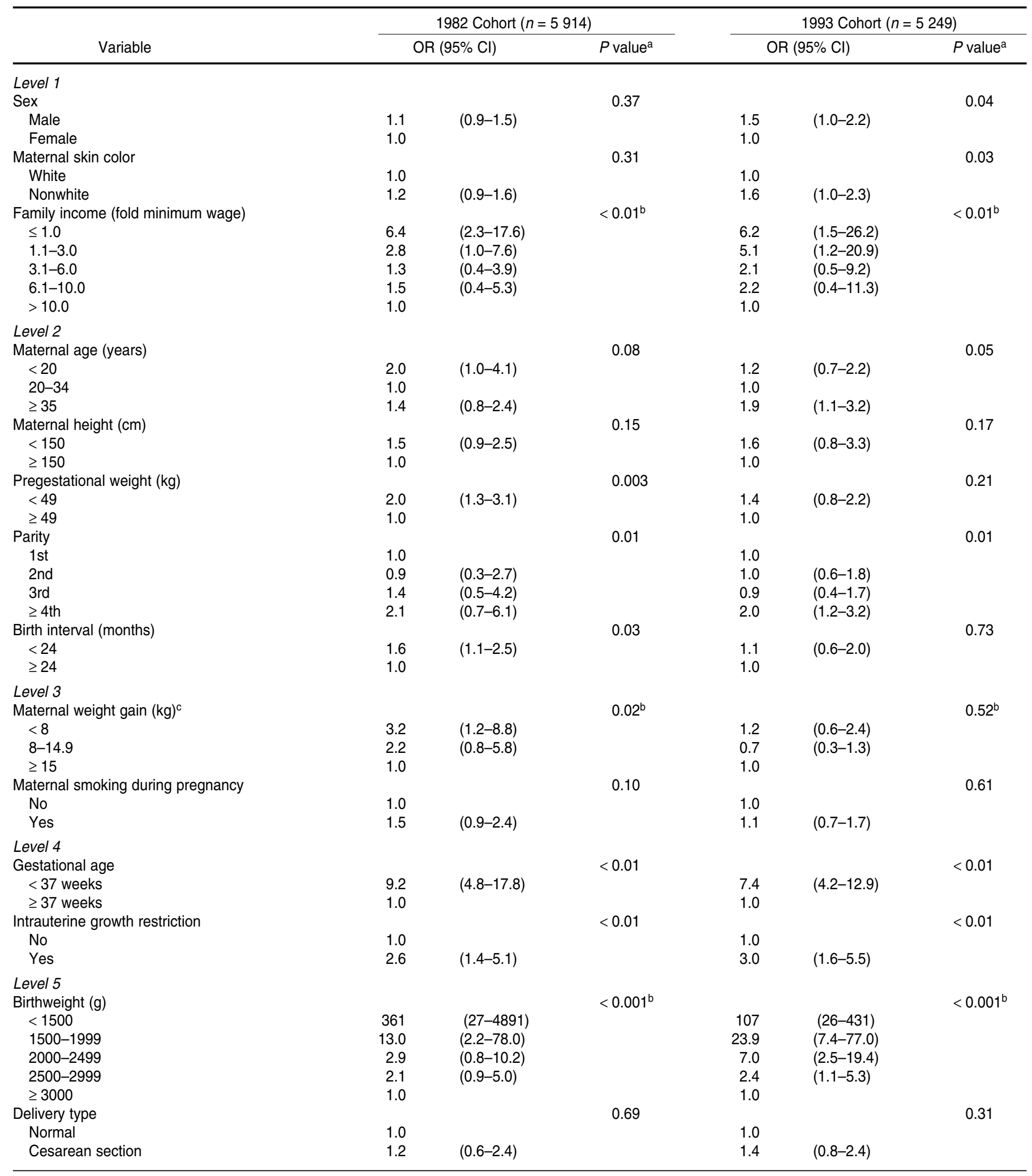

a Likelihood ratio test.

b Likelihood ratio test for linear trend.

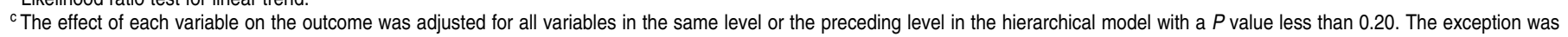
maternal weight gain during pregnancy, which was also adjusted for gestational age. 
TABLE 4. Etiologic fraction (EF) of selected exposures on the risk of infant mortality, Pelotas, Brazil, 1982-1993

\begin{tabular}{lcc}
\hline & $\begin{array}{c}1982 \\
(n=5914)\end{array}$ & $\begin{array}{c}1993 \\
(n=5249)\end{array}$ \\
\cline { 2 - 3 } \multicolumn{1}{c}{ Exposure } & $\mathrm{EF}$ & $\begin{array}{c}\mathrm{EF} \\
(\%)\end{array}$ \\
\hline Family income & 34.7 & 42.2 \\
Birthweight & 6.7 & 9.6 \\
Intrauterine growth restriction & 2.8 & 4.2 \\
Gestational age & 2.2 & 4.4 \\
Parity & 2.7 & 2.7 \\
\hline
\end{tabular}

TABLE 5. Logistic regression analyses for change in infant mortality rate (IMR) between the 1982 and 1993 cohorts (Pelotas, Brazil) after adjustment for different combinations of risk factors

\begin{tabular}{lccc}
\hline & \multicolumn{2}{c}{ Cohort } & \\
\cline { 2 - 3 } \multicolumn{1}{c}{ Analysis } & 1982 & $\begin{array}{c}1993 \\
\text { OR }(95 \% \text { Cl })\end{array}$ & $\begin{array}{c}\text { Expected IMR 1993 } \\
\text { (per 1 000) }\end{array}$ \\
\hline Unadjusted & 1.0 & $0.58(0.46-0.73)$ & 21 \\
Adjusted for maternal variables & 1.0 & $0.70(0.49-0.99)$ & 25 \\
Adjusted for newborn variables & 1.0 & $0.43(0.31-0.59)$ & 15 \\
Adjusted for maternal and newborn variables & 1.0 & $0.42(0.25-0.69)$ & 15 \\
\hline
\end{tabular}

improvements during the study period in terms of family income (Table 1) but socioeconomic inequities persisted over time. In both cohorts, the infant mortality ratio among the poorest groups was more than six times as large as among children born to the wealthiest families. These differentials have been described previously (12). Several maternal characteristics also improved during the study period, e.g., pregestational weight, height, weight gain during pregnancy, birth interval, and smoking. However, three other factors that are traditionally associated with infant mortality increased in prevalence: the proportion of adolescent mothers, of high-parity women, and of those with nonwhite skin color. All three factors are associated with poverty, which is an important risk factor per se for infant mortality. After adjustment for socioeconomic level, the effect of these three variables on infant mortality was minimized.

The crude difference between white and nonwhite mothers in terms of child survival (Table 2) was much larger than the adjusted difference (Table 3). Maternal age showed a Ushaped association with child survival, with younger and older mothers at higher risk of losing their children (13). The increased risk of adolescent mothers in 1982 disappeared in the adjusted analysis, showing that the crude effect was due to confounding by socioeconomic variables. On the other hand, the increased risk of infant mortality for infants born to older mothers persisted after adjustment.

Overall, most changes in family and maternal risk factors during the study period were favorable. However, we noted some ominous changes in certain newborn-related characteristics. Low birthweight, a major risk factor for infant mortality (14), increased slightly from $9.0 \%$ to $9.8 \%$, while mean birthweight declined by $30 \mathrm{~g}$. There was a substantial increase in preterm deliveries from $6.3 \%$ to $10.8 \%$, and the proportion of infants with IUGR also increased from $14.8 \%$ to $16.7 \%$. As noted, the figures for these last two variables should be interpreted with caution because of the high proportion of cases in which information on gestational age was missing. Because the increase in preterm deliveries was so marked, it is unlikely to be explained by reporting error. Moreover, the small increase in the prevalence of IUGR may not be real. The reductions in birthweight and in gestational age in Pelotas were probably due to changes in the use of medical interventions to terminate pregnancy, or to an increase in maternal risk factors for premature delivery. Because maternal risk factors did not increase markedly in Pelotas (7), medical interventions were probably responsible for these negative changes in birthweight and preterm delivery. This issue has been discussed elsewhere (7).

In addition to changes in family, maternal and newborn characteristics, infant mortality is also affected by variations in survival rates within each category of risk factor. Table 2 shows that there were impressive declines in infant mortality in nearly all risk categories, except for children born to mothers aged 35 years or more, and for those whose mothers gained $15 \mathrm{~kg}$ or more during pregnancy. The reasons for these discrepant results are unclear, and we cannot rule out the possibility of chance findings due to multiple comparisons.

A formal way of examining the role of changes in risk factor distributions and improved survival within risk factor categories is to examine how much mortality would be reduced had the frequency of risk factors remained constant between 1982 and 1993. This analysis, presented in Table 5, shows that the crude infant mortality rate decreased from 36 to 21 per 1000 during the period we studied. Had family and maternal factors remained unchanged, the decline would be less marked, from 36 to 25 . However, the decline would have been even greater (resulting in an infant mortality rate of 15 per 1000 in 1993) if birthweight had not declined and preterm deliveries had not increased.

In the 1982 cohort, information on environmental risk factors for post- 
neonatal mortality was collected only for surviving children, who were visited at 12 months of age or later. Because this information was not available for children who died, it was not possible to estimate the impact of environmental factors on mortality. For example, $76.2 \%$ of the families of surviving children had water inside the home in 1982, and this proportion increased to $84.4 \%$ in 1993 . A similar increase was observed for flush toilets $(75.4 \%$ in $1982,84.1 \%$ in 1993). No changes were observed in crowding (number of bedrooms or number of persons per bedroom). Infant feeding practices also changed slightly during the period: the median duration of breastfeeding increased from 3.1 to 4.0 months. Improvements in water, sanitation and feeding, however, are unlikely to account for the large decline in mortality. These findings support the hypothesis that changes in infant health care, rather than risk factor distribution, were responsible for most of the observed reduction in infant mortality.

In a previous publication we described changes in cause-specific mortality rates (15). Infant mortality due to perinatal causes decreased from 15.4 to 11.1 per 1000 (a $28 \%$ decrease) between 1982 and 1993, while deaths due to congenital malformations remained stable (4.5 and 4.8 per 1000$)$. On the other hand, mortality due to infectious diseases fell dramatically from 11.4 to 3.2 per 1000 (a 72\% decrease). The decrease in deaths from poorly-defined causes-from 4.0 to 1.1 per $1000(73 \%$ reduction)_-was also notable. These findings are consistent with improvements observed in Pelotas in health care and in the coverage of preventive interventions in 1993 (16). For example, there were no neonatal intensive care units in the city in 1982, but by 1993 three neonatal intensive care units had been created. In the late 1980s a national health system was created in Brazil, which led to improved access to health care for the whole population (17). Specifically, several positive changes occurred in Pelotas after the creation of the Sistema Único de Saúde (Unified Health System). Virtually all pregnant women received some antenatal care: the mean number of antenatal care consultations rose to 7.7 per mother in 1993, and the proportion of births attended by obstetricians and pediatricians rose significantly between 1982 and 1993 (7).
In conclusion, our analysis of two population-based birth cohorts suggests that the reduction in mortality in 1993 compared to 1982 cannot be ascribed to improvements in general social conditions or reductions in the prevalence of risk factors, but is more likely the result, in large part, of improved access to and coverage for health services.

Acknowledgments. This analysis was supported by the Wellcome Trust initiative "Major Awards for Latin America on Health Consequences of Population Change." Earlier phases of the 1982 and 1993 cohort studies were funded by the International Development Research Center (Canada), the World Health Organization (Department of Child and Adolescent Health and Development, and Human Reproduction Program), the Overseas Development Administration (United Kingdom), the European Union, the United Nation's Development Fund for Women, the National Program for Centers of Excellence (Brazil), the National Research Council (Brazil), and the Ministry of Health (Brazil).

\section{REFERENCES}

1. Puffer RR, Serrano CV. Patterns of mortality in childhood: the Inter-American Investigation of Mortality in Childhood. Washington, D.C.: PAHO; 1973. (Scientific Publication no. 262).

2. Schneider MC, Castillo-Salgado C, LoyolaElizondo E, Bacallao J, Mujica OJ, Vidaurre M, et al. Trends in infant mortality inequalities in the Americas: 1955-1995. J Epidemiol Community Health. 2002;56:538-41.

3. Ahmad OB, Lopez AD, Inoue M. The decline in child mortality: a reappraisal. Bull World Health Organ. 2000;78:1175-91.

4. Wagstaff A, Bustreo F, Bryce J, Claeson M; WHO-World Bank Child Health and Poverty Working Group. Child Health: reaching the poor. Am J Public Health. 2004;94:726-36.

5. Victora CG, Wagstaff A, Schellenberg JA, Gwatkin D, Claeson M, Habicht JP. Applying an equity lens to child health and mortality: more of the same is not enough. Lancet. 2003; 362:233-41.

6. Goldani MZ, Barbieri MA, Silva AA, Bettiol $H$. Trends in prenatal care use and low birthweight in southeast Brazil. Am J Public Health. 2004;94:1366-71.

7. Barros FC, Victora CG, Barros AJD, Santos IS, Albernaz E, Matijasevich A, et al. The challenge of reducing neonatal mortality in middleincome countries: findings from three Brazilian birth cohorts, 1982-1993-2004. Lancet. 2005; 365:847-54.

8. Wagstaff A, van Doorslaer E. Overall versus socioeconomic health inequality: a measurement framework and two empirical illustrations. Health Econ. 2004;13:297-301.

9. Williams RL, Creasy RK, Cunnigham GC, Hawes WE, Norris FD, Tashiro M. Fetal growth and perinatal viability in California. Obstet Gynecol. 1982;59:624-32.

10. Victora CG, Huttly SR, Fuchs SC, Olinto MT. The role of conceptual frameworks in epidemiological analysis: a hierarchical approach. Int J Epidemiol. 1997;26:224-7.

11. Victora CG, Barros FC, Tomasi E, Menezes AM, Horta BL, Weiderpass E, et al. Tendências e diferenciais na saúde materno-infantil: delineamento e metodologia das coortes de 1982 e 1993 de mães e crianças de Pelotas, Rio Grande do Sul. Cad Saude Publ. 1996;12: S7-14.

12. Victora CG, Vaughan JP, Barros FC, Silva AC, Tomasi E. Explaining trends in inequities: evidence from Brazilian child health studies. Lancet. 2000;356:1093-8.
13. Davis RA. Adolescent pregnancy and infant mortality: isolating the effect of race. Adolescence. 1988;23:899-908.

14. Matteson DW, Burr JA, Marshall JR. Infant mortality: a multi-level analysis of individual and community risk factors. Soc Sci Med. 1998;47:1841-54.

15. Menezes AMB, Victora CG, Barros FC, Albernaz E, Menezes FS, Jannke HA, et al. Mortalidade infantil em duas coortes de base populacional no Sul do Brasil: tendências e diferenciais. Cad Saude Publ. 1996;12:S79-86.

16. Costa JSD, Victora CG, Barros FC, Halpern R, Horta BL, Manzolli P. Assistência médica materno-infantil em duas coortes de base populacional no Sul do Brasil: tendências e diferenciais. Cad Saude Publ. 1996;12:S59-66.

17. Monteiro CA, org. Velhos e novos males da saúde no Brasil: a evolução do país e de suas doenças. São Paulo: HUCITEC/NUPENS/ USP; 1995.

Manuscript received on 11 February 2005. Revised version accepted for publication on 2 August 2005. 
RESUMEN Objetivos. Comparar dos cohortes de nacimiento tomadas de la población en general a fin de evaluar las tendencias observadas en las tasas de mortalidad de menores de un año y la distribución de los factores de riesgo asociados con ella, así como los cambios sufridos por ambas cosas al cabo de un período de 11 años.

\section{La mortalidad de menores de un año en Pelotas, Brasil: comparación de factores de riesgo en dos cohortes de nacimiento}

Métodos. Se analizaron los datos procedentes de dos cohortes de nacimiento prospectivas (1982 y 1993) tomadas de la población en general. En ambos estudios se abarcó a todos los niños que nacieron en hospitales (>99\% de todos los nacidos) en la ciudad de Pelotas, en el sur del Brasil. La mortalidad de menores de un año se monitoreó mediante una vigilancia de todos los hospitales de maternidad, registros de defunción y cementerios.

Resultados. Los niños que nacieron vivos fueron 5914 en 1982 y 5249 en 1993.La tasa de mortalidad de menores de un año se redujo en $41 \%$, es decir, de 36,0 por cada 1000 nacidos vivos en 1982 a 21,1 por cada 1000 nacidos vivos en 1993. Los factores socioeconómicos y maternos mostraron una tendencia a mejorar a lo largo del período de estudio, pero se observaron cambios desfavorables en el peso al nacer y en la edad gestacional. La pobreza, la paridad elevada, el peso bajo al nacer, el parto prematuro y la restricción del crecimiento intrauterino fueron los principales factores de riesgo de muerte en menores de un año en ambas cohortes. La reducción de $41 \%$ en la mortalidad de menores de un año que se observó entre 1982 y 1993 habría sido aun más marcada si la prevalencia de los factores de riesgo se hubiera mantenido constante durante el período estudiado.

Conclusiones. Se produjeron reducciones muy notables de la mortalidad de menores de un año que no obedecieron a cambios en los factores de riesgo examinados. En vista de que no se observó ninguna reducción de las grandes desigualdades sociales documentadas en la cohorte de 1982, es muy probable que el descenso de la mortalidad de menores de un año haya sido en gran medida consecuencia de mejoras en la atención de salud.

Palabras clave
Mortalidad infantil, desigualdad, estudios de cohortes, estudios prospectivos, países en desarrollo.

\section{Importante reconocimiento a científica latinoamericana}

Consagración a la ciencia y abnegación ante la ardua y muchas veces anónima tarea de salvar vidas desde un laboratorio son dos de los principales atributos de la doctora María Guadalupe Guzmán que justifican con creces su selección para exponer —junto a otros diez científicos destacados de todo el mundo- sus experiencias en la serie "Voces Mundiales de la Ciencia", con la que la revista Science celebra en 2005 su $125 .{ }^{\circ}$ aniversario.

La grave epidemia de dengue que asoló a Cuba en 1981 — seis años después de graduarse como médica la doctora Guzmán— repercutió de manera decisiva en la joven viróloga, quien en años sucesivos participó activamente como investigadora y luego como líder en muchas de las principales investigaciones que han permitido combatir eficazmente más de una epidemia de dengue en su país y en el extranjero. Entre los resultados más notables de su trabajo se encuentran la identificación de los diferentes serotipos de dengue que han circulado en Cuba, la caracterización clínica y epidemiológica de la enfermedad y el establecimiento de un sistema nacional para su vigilancia y control.

Como protagonista de los más importantes logros alcanzados por Cuba en la lucha contra el dengue y otras enfermedades virales, la doctora Guzmán —o Lupe, como la conocen sus colegas y alumnos en Cuba y en los numerosos países de varias regiones donde ha prestado sus servicios como médica y especialista en virología - es una voz autorizada de la ciencia latinoamericana y mundial.

María Guadalupe Guzmán es miembro de la Academia de Ciencias de Cuba y de la Academia de Ciencias del Tercer Mundo (TWAS) y directora del Centro Colaborador de la Organización Panamericana de la Salud (OPS) y la Organización Mundial de la Salud (OMS) para el Estudio de las Enfermedades Víricas, que radica en el Instituto de Medicina Tropical Pedro Kourí (IPK), en Ciudad de La Habana, Cuba. Recientemente ha tomado bajo su mando el Centro Colaborador de la OPS para el Estudio del Dengue y su Control y es miembro del Consejo de la Fundación del Foro Mundial sobre Investigaciones Sanitarias (Global Forum for Health Research). Integra varios comités de expertos de la OPS, la OMS y el Programa Especial para la Investigación y el Entrenamiento en Enfermedades Tropicales (TDR). La Academia de Ciencias de Cuba la ha premiado en 14 oportunidades como autora de resultados científicos destacados de la ciencia cubana. La Dra. Guzmán es autora de numerosos trabajos publicados en la Revista Panamericana de Salud Pública/Pan American Journal of Public Health y uno de sus árbitros más activos. 